\title{
HYDROLOGICAL AND HYDRAULICS INVESTIGATION FOR THE DESIGN OF BRIDGE ACROSS AJOWA RIVER AT WUCHALE TOWN AMHARA REGION SOUTH WOLLO ETHIOPIA
}

\author{
Birhanu Haile Gedamu \\ Department of Hydraulics and water resource Engineering, Kombolcha Institute of \\ Technology Wollo University, Kombolcha, Ethiopia
}

Vijaykumar

Department of Civil Engineering, Kombolcha Institute of Technology Wollo University, Kombolcha, Ethiopia

\begin{abstract}
Bridges are constructed across the river to create way from one end to another end. The purpose of this study is to carry out hydrological analysis of the rivers, streams and flood paths which intersect with the proposed bridge, to estimate their different return floods magnitudes in order to size the openings of the proposed bridges. During the study the following tasks have been carried out analysis and interpretation of different topographic maps, soils map, satellite imagery and DEM (Digital Elevation Model) data collection of data and analysis for un-gauged rivers and streams, estimation of flood magnitudes by applying different rainfall-runoff models, Sizing of bridges, Provide designs type, size, and location of bridge Assess scour potential at bridge locations. The flood magnitudes at the bridge site are the function of geomorphology, geology, rainfall; soil and land use or land cover within the catchments of the rivers and streams crossing the road.
\end{abstract}

Keywords: River, Bridge, Rainfall, Soil, Flood.

Cite this Article: Birhanu Haile Gedamu and Vijaykumar, Hydrological and Hydraulics Investigation for the Design of Bridge across Ajowa River at Wuchale Town Amhara Region South Wollo Ethiopia. International Journal of Civil Engineering and Technology, 11(5), 2020, pp. 115-124.

https://iaeme.com/Home/issue/IJCIET?Volume=11\&Issue=5

\section{INTRODUCTION}

As we know most of the bridges are very costly structures, spending millions of monies, but most of the bridges does not last longer life. If hydrological investigations are not properly 
carried out bridge can fail due to such reasons [1]. In hydrology and hydraulics, the discharge is the volume of rate of water flow through a given cross-sectional area. It includes any suspended solids, dissolved chemicals and biologic material in addition to the water itself. The catchment of a river area a certain location is determined by the surface area of all land which drains toward the river from above that point. The river's discharge at that location depends on the rainfall intensity of the catchment area and the inflow and outflow of groundwater to or from the area of river, stream modifications such as rivers and irrigation diversions [2]. As a result of flooding, it is important for the flood management department to prevent the effects of flood by employing flood mitigation measures like infrastructure development and river trainings. River floods carried by storms are major devastations and had caused damages structures worth billions during a flood [3]. Design of flood magnitudes are required for the design of bridges openings, drainage of air ports, and construction of flood walls and levees. The damages due to the devastating floods can be minimized by various flood control measures [4]. HEC-RAS is equipped to model a network of channels, a single river reach. It is made easy in order to model some complex flow conditions by using the HEC-RAS one-dimensional approach. It is able to modeling subcritical, supercritical and mixed flow regime along with the effects of bridges, culverts, weirs, and structures. It is costly and difficult to do constant measurement of the rivers flow in normal situation and in flood risk situations [5]. The river system often consists of a main river and several small tributaries. The Slope of main rivers is often smaller than tributaries. Storm brings strong rainfall in short period, which causes floods surge in a short period. Most of the large amount of debris with floods is blocking near span make bridge failure. Hydrological and hydraulics investigations of the bridges should be carried out within a bridge community in a certain rain catchment area [6]. HEC-RAS (Hydrologic Engineering Centre- River Analysis System) is numerical analysis and design software it gives the details of flood profiles. The software is easily available and it has precise calibration accuracy also [7]. Using a computational model has many advantages e.g. Calculating flood elevations with an accuracy written and documented programs is a scientific and analytical technique [8].

\section{STUDY AREA}

The proposed Ajowa bridge project is found in South Wollo, of the Amhara Regional State. The proposed bridge connects main Wuchale town with Robit keble. The proposed ajowa river bridge control points like ajowa River.

\section{OBJECTVES}

- Rainfall analysis and determination of different return period flood magnitudes for the rivers, streams and flood paths crossing the Ajowa bridge project.

- Identification of different sections of the bridge project exhibiting unstable hydrological conditions (e.g. Erosion) and the causes of such instability, and the proposal of appropriate mitigation measures.

- Determination of appropriate sizes of waterway opening for the various watercourses as a major hydrological parameter in determining a suitable category of conduit in each case, i.e. bridge.

\section{METHODOLOGY AND APPROCH}

HEC-RAS Software the Hydrologic Engineering Center River Analysis System (HEC-RAS) is a program developed by the US Army Corps of Engineers. The HEC-RAS is numerical software for hydrology calculations. It is widely used in one-dimensional water surface profile 
calculations in case of steady and unsteady river flow regimes. In addition, it contains components for one-dimensional sediment transport numerical analysis [9]. There are various recognized methods and approaches for hydrologic or hydraulic design of drainage facilities.

- Modified Rational Method (MRM)

- Soil Conservation Service (SCS) graphical Method

Detailed Hydrological investigations are carried out for all the bridge structures with careful analysis of Digital Elevation Model (DEM 30*30) resolution, available maps and field investigations. Catchment areas, rainfall, runoff duration intensity relationships, catchment run-off characteristics and channel slopes or discharge characteristics, for each catchment area has been calculated.

\subsection{The Rational Method}

The Rational Method is the most accurate for calculating the design storm peak run-off for area up to $50 \mathrm{ha}\left(0.5 \mathrm{~km}^{2}\right)$. The Method can be employed to small rural catchment area if they do not exceed $0.5 \mathrm{~km}^{2}$. The consequences of using the Rational Method to larger catchment is to produce an over calculate of discharge.

The rational formula is expressed as:

$$
\mathrm{Q}=0.278 \mathrm{C} \mathrm{I} \mathrm{A}
$$

Where,

$\mathrm{Q}=$ Maximum rate of runoff in $\mathrm{m}^{3} / \mathrm{s}$

$\mathrm{C}=$ Runoff coefficient representing a ratio of runoff to rainfall

$\mathrm{I}=$ Rainfall intensity for a duration equal to the time of concentration and for design return period in $\mathrm{mm} /$ hour.

$\mathrm{A}=$ Catchment area tributary to the design location in $\mathrm{km}^{2}$

\subsubsection{Runoff Coefficient (C)}

Values shown in Table 3 are stipulated in ERADDM for determination of $\mathrm{C}$ (for non-urban catchments), depending on terrain type and hydrologic soil grouping.

Table 1 Runoff Coefficients, C Value (Adopted from ERA, 2013 and FHWA manual)

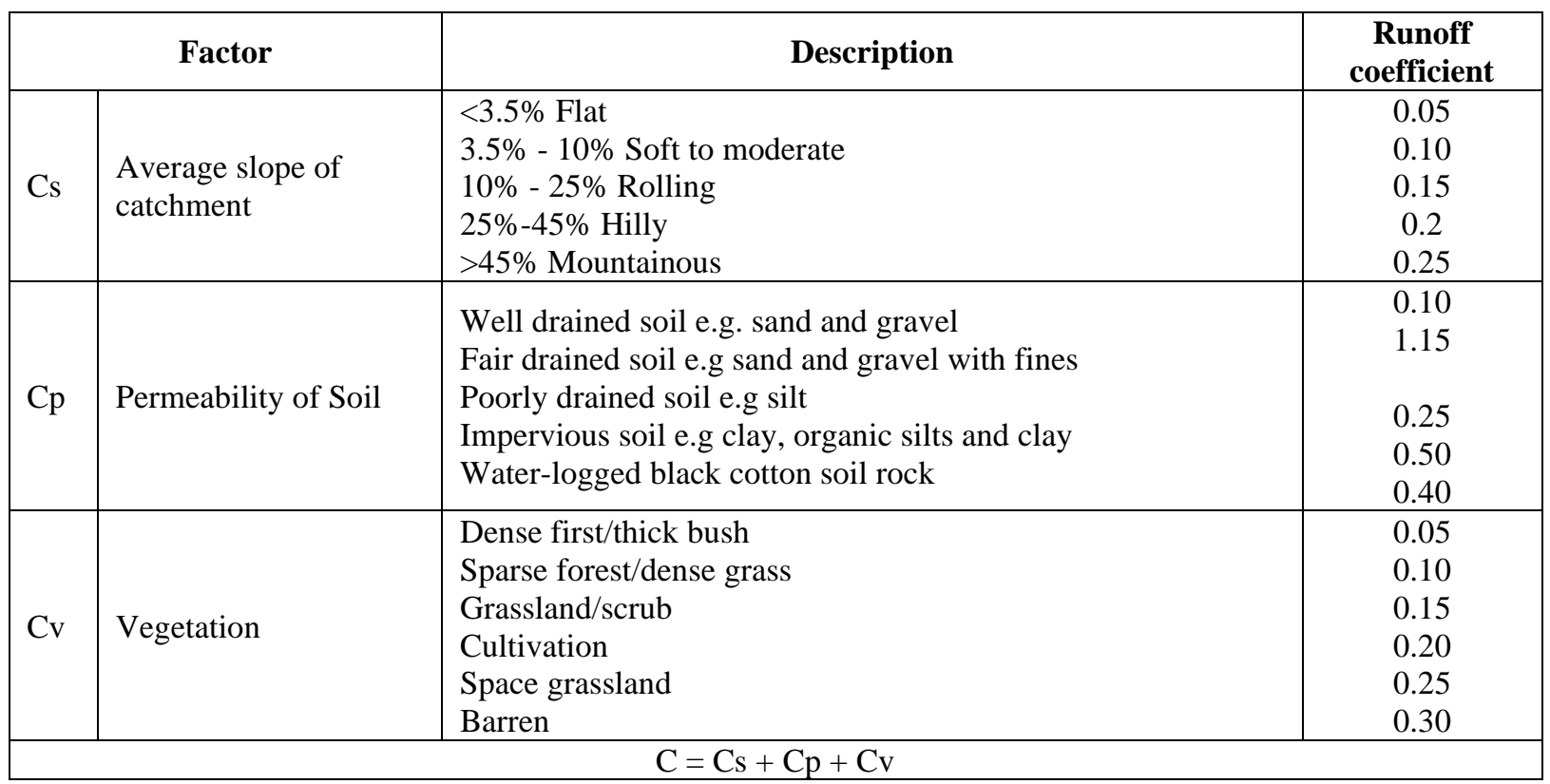




\subsubsection{Rainfall Intensity (I)}

ERADDM divides the country into different rainfall zones and for each gives Intensity Duration - Frequency IDF curves, Project IDF curve has been used of ERA regional IDF curve and adopted for this particular project of region $\mathrm{C}$.

\subsubsection{Time of Concentration (Tc)}

The rainfall intensity used in the rational method is determined from the time of concentration (Tc). Tc is defined as the time required for surface runoff water to flow hydraulically from the remotest point of the catchment to the point of exit.

$$
\mathrm{T}_{\mathrm{c}}=0.0147 * \mathrm{~L}^{1.155} \mathrm{H}^{-0.385} \text { (Kirpich /SCS Equation) }
$$

Where

$\mathrm{T}_{\mathrm{c}}=$ Time of concentration in minutes

$\mathrm{L}=$ Maximum length of flow in meter

$\mathrm{H}=$ Elevation difference between the most remote and outlet in meter

\subsubsection{Frequency Factor}

As per ERADDM, the frequency factor is used to magnify the less frequent storms, i.e. storms with recurrence interval greater than 10year.

Table 2 (ERADDM) Frequency Factors for Rational Formula

\begin{tabular}{|c|c|}
\hline Recurrence Interval (years) & $\mathbf{C}_{\mathbf{f}}$ \\
\hline 5 & 1.0 \\
\hline 10 & 1.0 \\
\hline 25 & 1.1 \\
\hline 50 & 1.2 \\
\hline 100 & 1.25 \\
\hline
\end{tabular}

\subsection{Soil Conservation Service (SCS) method}

This method is developed by the U. S. Soil Conservation Service for estimation rates of runoff and required same basic data as the Rational Method. The SCS approach, however, is more sophisticated in that it considered also the time distribution of the rainfall intensity, the initial rainfall intensity losses to interception and depression storage, and an infiltration rate is decreases during the course of storm. With the SCS method, the direct run-off can be estimated for any storm, either real or fabricated, by subtracting infiltration and other losses from the rainfall to obtain the precipitation excess.

\subsubsection{Catchment Area}

The catchments area can be estimated from topographic maps and field surveys. For large catchment areas it can be necessary to divide the area into sub-catchment areas to account for major land use changes, obtain analysis results at different points within the catchment area, or locate storm water drainage structures and assess their effects on the flood flows. A field inspection of existing or proposed drainage systems has been made to estimate if the natural drainage divides has been changed.

\subsubsection{Rainfall}

The SCS method is based on a one-day storm event which is a Type-II-time distribution. The Type-II storm distribution is a typical time distribution which SCS has prepared from rainfall data records. It is useful for interior rather than coastal regions and will be appropriate to Ethiopia. To utilize this distribution, it is necessary for the user to obtain the one-day rainfall values for the frequency of the design storm required. 


\subsubsection{Rainfall Runoff equation}

The relationship between accumulated rainfall and accumulated run-off is derived by SCS from experimental plots for various hydrologic and vegetative cover conditions. Data for land treatment measures, such as contouring and terracing, from experimental catchment area was included. The equation was developed mainly for small catchment areas for which daily rainfall and catchment area data are primarily available. It was developed from recorded storm data that includes total value of rainfall in a calendar day but not its distribution with respect to time. The SCS run-off equation for estimating direct run-off from one-day storm rainfall.

$$
\text { The equation is: } \quad Q=\frac{(\mathrm{P}-\mathrm{Ia})^{2}}{(\mathrm{P}-\mathrm{Ia})+\mathrm{S}}
$$

Where:

$\mathrm{Q}=$ accumulated direct runoff in $\mathrm{mm}$

$\mathrm{P}=$ accumulated rainfall (potential maximum run-off) in $\mathrm{mm}$

Ia = initial abstraction including surface storage, interception and infiltration prior to runoff in $\mathrm{mm}$

$$
\mathrm{S}=\text { potential maximum retention in } \mathrm{mm}
$$

The relationship between Ia and $\mathrm{S}$ was developed from experimental catchment area data. It removes the necessity for estimating Ia for common usage.

The empirical relationship used in the SCS runoff equation is:

$$
\mathrm{Ia}=0.2 * \mathrm{~S}
$$

Substituting $0.2 * \mathrm{~S}$ for Ia, the SCS rainfall-runoff equation becomes:

$$
Q=\frac{(\mathrm{P}-0.2 * \mathrm{~S})^{2}}{(\mathrm{P}+0.8 * \mathrm{~S})}
$$

$\mathrm{S}$ is related to the soil and cover conditions of the catchment area through the $\mathrm{CN}$.

$\mathrm{CN}$ has a range of 0 to 100 , and $\mathrm{S}$ is related to $\mathrm{CN}$ by:

$$
\mathrm{S}=\frac{25400}{\mathrm{CN}-254}
$$

\subsubsection{Run-off Factors}

Run-off is rainfall excess the value by which rainfall exceeds the ability of the land to infiltrate or retain rainwater. The principal physical catchment area characteristics affecting the relationship between rainfall and runoff are land use, land treatment, soil types, and land slope.

\section{RESULTS AND DISCUSION}

\subsection{HEC-RAS (Hydraulic Engineering Center-River Analysis System) Analysis Result}

The main objective of the HEC-RAS (Hydraulic Engineering Center-River Analysis System) program is quite simple to compute water surface elevations at all locations of interest for either a given set of flow data or by routing hydrographs through the system. 


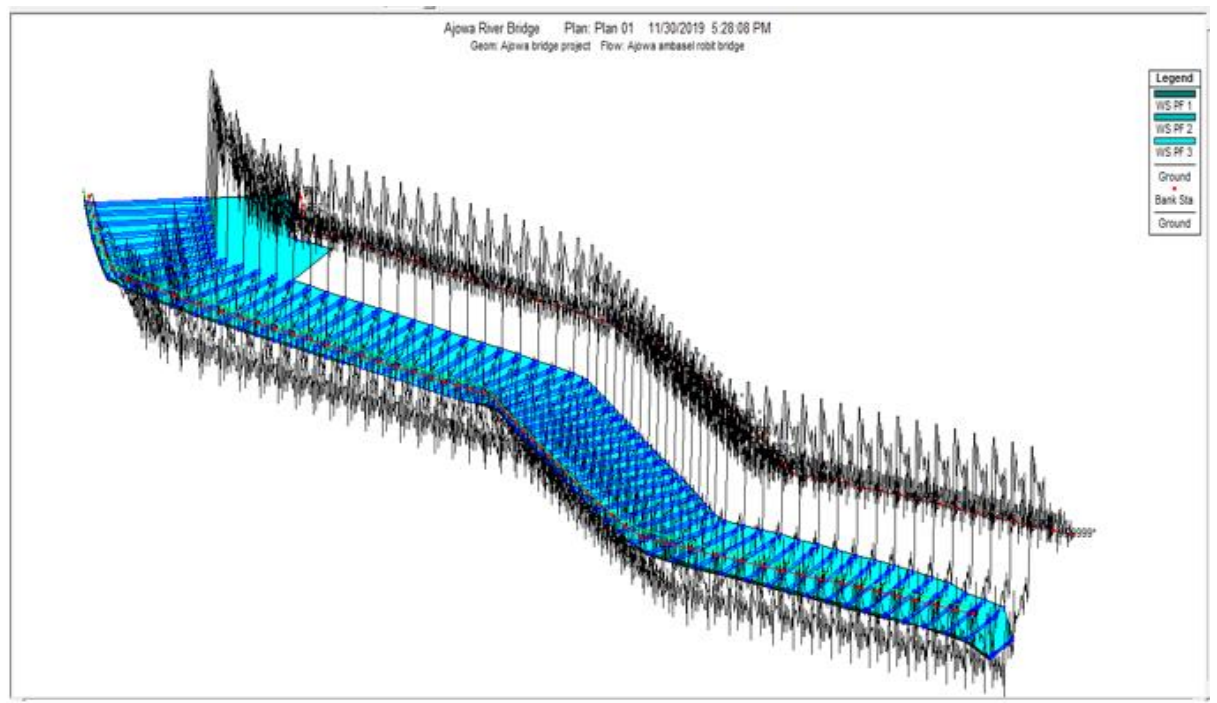

Figure 1 XYZ Perspective of Ajowa River

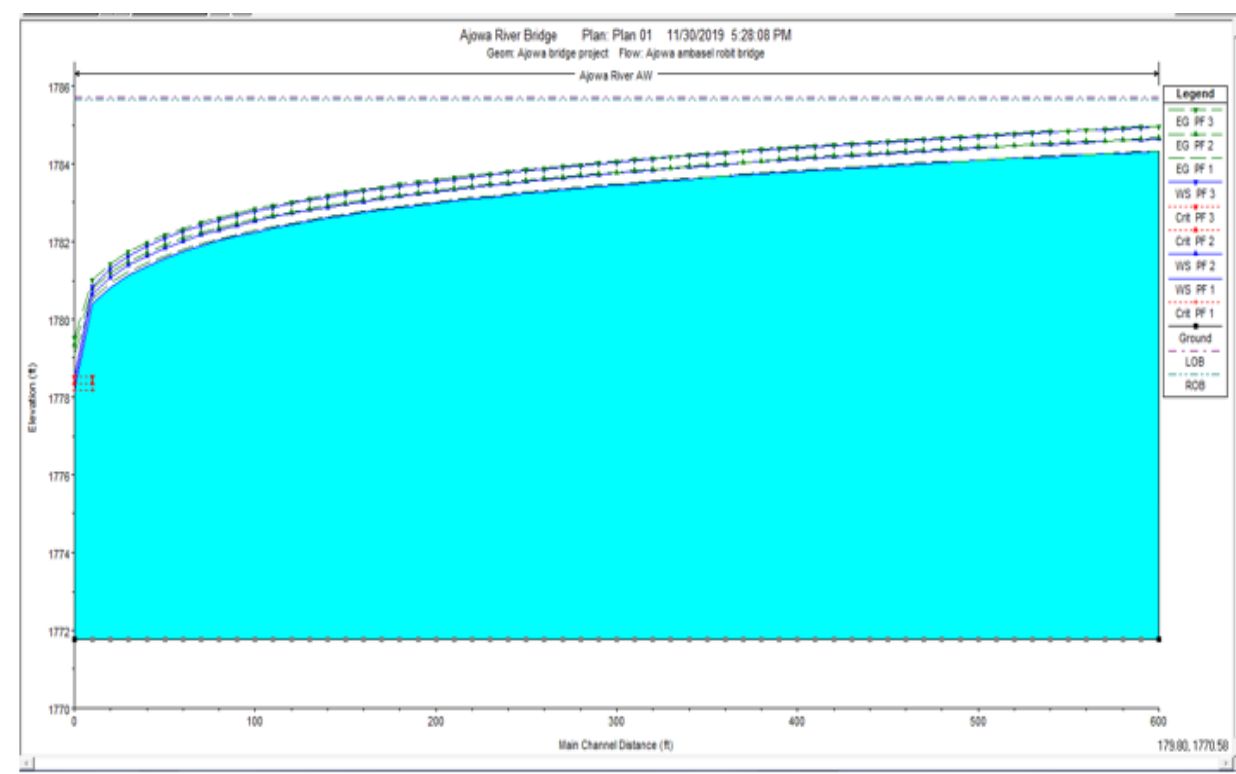

Figure 2 Water surface profile of Ajowa river

\subsection{Bridge Design Criteria}

The following are the criteria related to the hydraulics analysis for the sufficiency of the bridge. Simple spread sheet and HEC-RAS software has been used for the analysis.

Design Floods: The purposes of the evaluation of backwater, clearance, and overtopping, design floods have been determined.

Backwater: Backwater increases over existing condition up to $0.5 \mathrm{~m}$ during the passage of the 100year flood. Furthermore, backwater shall not significantly increase flood damage to property up-stream of the crossing.

Clearance: The minimum clearance conforming to the requirements of the Bridge Design manual will be provided between the design approach, water surface elevation and the low chord of the bridge to allow passage debris. Clearance will be according to ERA's Bridge Design Manual whose values are as stated below table. 
Table 3 Free board recommendation ERA 2013

\begin{tabular}{|c|c|}
\hline Discharge, $\mathbf{Q}\left(\mathbf{m}^{\mathbf{3}} / \mathbf{s}\right)$ & Freeboard $(\mathbf{m})$ \\
\hline $0-3.0$ & 0.3 \\
\hline $3.0-30$ & 0.6 \\
\hline $30-300$ & 0.9 \\
\hline$>300.0$ & 1.2 \\
\hline
\end{tabular}

\subsection{Hydrologic and Hydraulics Investigations}

Following are the preliminary investigations, site visit has been carried out for hydrologic and hydraulics investigations of streams and major rivers at Ajowa. In this regard, the location of rivers is identified physically, channel measurement and hydraulic condition of the rivers has been also observed and noted. Thus, it is confirmed that all of the rivers are seasonal. Moreover, site Hydrologic and hydraulic data has been collected; the river characteristics and their locations are studied. The summary of recommended hydrologic and hydraulic analysis is given in the table below table.

Table 4 Summary of hydrology/ hydraulics of Bridges

\begin{tabular}{|c|c|c|c|c|c|c|}
\hline \multirow{2}{*}{ S.No } & \multirow{2}{*}{ Station } & \multirow{2}{*}{$\begin{array}{c}50 \text { yr. Peak } \\
\text { Discharge Q } \\
\left(\mathrm{m}^{3} / \mathrm{s}\right)\end{array}$} & \multirow{2}{*}{$\begin{array}{c}100 \text { yr. Peak } \\
\text { Discharge Q } \\
\left(\mathrm{m}^{3} / \mathrm{s}\right)\end{array}$} & \multicolumn{2}{|c|}{ Recommended size } & \multirow{2}{*}{ Remark } \\
\hline & & & & $\operatorname{Span}(\mathbf{m})$ & Height(m) & \\
\hline 1 & & 264.016 & 294.209 & 38 & 3.7 & Geometrically detected \\
\hline
\end{tabular}

Table 5 Ajowa River Bridge design flood using USSCS (United States Soil Conservation Service)

\begin{tabular}{|c|c|c|c|c|}
\hline $\begin{array}{c}\text { Return period } \\
\text { (years) }\end{array}$ & $\begin{array}{c}\mathbf{q u}(\text { Unit peak } \\
\mathbf{d i s c h a r g e )} \\
\mathbf{m}^{\mathbf{3}} / \mathbf{s} / \mathbf{k m} \mathbf{m} / \mathbf{m m}\end{array}$ & $\begin{array}{c}\text { Catchment Area } \\
\left.\mathbf{( k m}^{\mathbf{2}}\right)\end{array}$ & $\begin{array}{c}\mathbf{Q} \text { depth of } \\
\text { runoff }(\mathbf{m m})\end{array}$ & $\mathbf{q p}=\mathbf{q u} * \mathbf{A} * \mathbf{Q}$ \\
\hline 25 & 0.10848 & 32.251 & 66.949 & 234.24 \\
\hline 50 & 0.10848 & 32.251 & 75.460 & 264.016 \\
\hline 100 & 0.10848 & 32.251 & 84.090 & 294.209 \\
\hline
\end{tabular}

Table 6 Ajowa River bridge catchment soil

\begin{tabular}{|c|c|c|c|c|}
\hline S.No & Item & Area (sq.km) & Percentage \% & Hydrological soil group \\
\hline 1 & Eutric cambisols & 1.387 & 4.30 & $\mathrm{~B}$ \\
\hline 2 & Eutric Regosols & 2.34 & 7.26 & $\mathrm{~A}$ \\
\hline 3 & Eutric leptosols & 28.524 & 88.44 & $\mathrm{D}$ \\
\hline \multicolumn{2}{|r|}{} & 32.251 & 100.00 & \\
\hline
\end{tabular}

Table 7 Ajowa River bridge catchment land use

\begin{tabular}{|c|l|c|c|c|c|}
\hline S.No & \multicolumn{1}{|c|}{ Item } & Area (sq.km) & Percentage \% & Land cover & Curve number \\
\hline 1 & Agricultural & 3.4245 & 10.62 & Dominantely cultivated & 80 \\
\hline 2 & Accacia bush land & 5.2096 & 16.15 & Agro pastorial & 82 \\
\hline 3 & Barren/sparsely Vg & 23.6169 & 73.23 & Agro pastorial & 94 \\
\hline \multicolumn{2}{|l}{} & Total & 32.251 & & \\
\hline
\end{tabular}


Hydrological and Hydraulics Investigation for the Design of Bridge across Ajowa River at Wuchale Town Amhara Region South Wollo Ethiopia

Table 8 Ajowa River Bridge Curve Number

\begin{tabular}{|l|c|c|c|}
\hline \multicolumn{1}{|c|}{ Item } & Area & CN & Product \\
\hline Agricultural /Cropland & 3.4245 & 80 & 273.96 \\
\hline Accacia bushland & 5.2096 & 82 & 427.1872 \\
\hline Barren/Sparsely Veget & 23.6169 & 94 & 2219.989 \\
\hline Total Average curve number & 32.251 & & 2921.14 \\
\hline \multicolumn{2}{|c|}{ CN } & 90.58 \\
\hline
\end{tabular}

Table 9 Ajowa Bridge Catchment Maximum Potential Retention (S)

\begin{tabular}{|c|c|c|c|}
\hline 25400 & $\mathrm{CN}$ & 254 & \\
\hline & 90.58 & & \\
\hline & 280.4304 & $\mathrm{~S}$ & 26.4 \\
\hline
\end{tabular}

Table 10 Ajowa River Bridge Catchment Initial Abstraction (Ia)

\begin{tabular}{|c|c|c|c|c|c|c|}
\hline $\mathrm{Ia}=0.2 * \mathrm{~S}$ & $\mathrm{P} * 25$ & $\mathrm{P} * 50$ & $\mathrm{P} * 100$ & $\mathrm{Ia} / \mathrm{P} * 25$ & $\mathrm{I} / \mathrm{P} * 50$ & $\mathrm{Ia} / \mathrm{P} * 100$ \\
\hline 5.29 & 92.52 & 101.48 & 110.5 & 0.057135 & 0.052 & 0.048 \\
\hline
\end{tabular}

Table 11 Ajowa River Bridge Direct runoff in mm depth, $\mathrm{Q}=(\mathrm{P}-0.25) 2 \div((\mathrm{P}+0.8 * \mathrm{~S}))$

\begin{tabular}{|c|c|c|c|c|c|c|c|c|}
\hline $\mathrm{Q} * \mathrm{~S}$ & $0.2 * \mathrm{~S}$ & $0.8 * \mathrm{~S}$ & $\mathrm{P} * 25$ & $\mathrm{Q} * 25$ & $\mathrm{P} * 50$ & $\mathrm{Q} * 50$ & $\mathrm{P} * 100$ & $\mathrm{Q} * 100$ \\
\hline 26.43 & 5.286 & 21.144 & 92.52 & 66.949 & 101.48 & 75.460 & 110.5 & 84.0 \\
\hline & 122.6244 & & 7609.755 & & 9253.269 & & 11069.97 & \\
\hline & & & 113.6644 & & & & 131.6444 & \\
\hline
\end{tabular}

Table 12 Ajowa Bridge Time Concentration for Over Land Flow

\begin{tabular}{|c|c|c|c|c|c|c|c|c|c|}
\hline \multirow{2}{*}{$\begin{array}{c}\text { Length } \\
\text { (km) }\end{array}$} & \multirow[b]{2}{*}{ Min Elv } & \multirow[b]{2}{*}{ Max Elv } & \multirow[b]{2}{*}{$\begin{array}{c}\text { Slope }=\mathbf{H} \div 1000^{*} \\
\mathbf{L}\end{array}$} & \multicolumn{3}{|c|}{ C Values } & \multirow[b]{2}{*}{ CVL } & \multirow[b]{2}{*}{$S^{\wedge} 0.5$} & \multirow[b]{2}{*}{$\begin{array}{c}\text { Tc }=0.604(\mathrm{CvL} \\
\left.\div \mathrm{S}^{0.5}\right)\end{array}$} \\
\hline & & & & $\begin{array}{c}\text { Barren/spar } \\
\text { sely veg }\end{array}$ & $\begin{array}{c}\text { Accacia bush } \\
\text { land }\end{array}$ & \begin{tabular}{|} 
Agricultu \\
ral
\end{tabular} & & & \\
\hline & & & & 23.6169 & 5.2096 & 3.4245 & & & \\
\hline \multirow[t]{4}{*}{6.678} & 1869.7 & 3011.1 & 0.1709 & 0.3 & 0.1700 & 0.2000 & 1.7923 & 0.4134 & 1.20 \\
\hline & & & & 7.08507 & 0.885632 & 0.6849 & & & \\
\hline & & & & & & 8.7 & & & \\
\hline & & & & CV weight & & 0.18 & & & \\
\hline
\end{tabular}

Table 13 Ajowa Bridge Time Concentration for Defined Water Course

\begin{tabular}{|c|c|c|c|c|c|c|}
\hline $\begin{array}{c}\text { Length } \\
(\mathbf{k m})\end{array}$ & $\begin{array}{l}\text { Elevation } \\
\text { 0.85L (m) }\end{array}$ & $\begin{array}{l}\text { Elevation } \\
\text { 0.1L(m) }\end{array}$ & $\begin{array}{c}S_{\mathrm{av}}=\mathrm{H}_{0.85 \mathrm{~L}}-\mathbf{H}_{0.10 \mathrm{~L}} \\
\left(\mathbf{1 0 0 0} *\left(0.75^{*} \mathrm{~L}\right)\right.\end{array}$ & $1000 *$ Sav & $0.87 * L^{\wedge} 2$ & $\begin{array}{c}T c=\left(0.87 L^{2}\right. \\
\left.\div 1000 * S_{\text {av }}\right)^{0.385}\end{array}$ \\
\hline \multirow[t]{4}{*}{5.61} & 2599.7 & \begin{tabular}{|l|}
1945.8 \\
\end{tabular} & 0.1554 & 155.413 & 27.381 & 0.51 \\
\hline & 4.7685 & 0.561 & & & & \\
\hline & 4768.5 & 561 & & & & \\
\hline & & & & Total Tc & $\mathrm{Tc}_{1}+\mathrm{Tc}_{2}$ & 1.71 \\
\hline
\end{tabular}

Table 14 Ajowa River Bridge Unit Peak Discharge

\begin{tabular}{|c|c|c|c|c|c|}
\hline Logtc & c1*Logtc & $(\operatorname{Logtc})^{\wedge} 2$ & $\begin{array}{c}\mathrm{C} 2 *(\operatorname{Logtc})^{\wedge} \\
2\end{array}$ & $\begin{array}{c}\mathrm{Co}+\mathrm{c} 1 * \operatorname{Logtc}+\mathrm{C} 2 \\
*(\operatorname{logtc})^{\wedge} 2\end{array}$ & $q u=\alpha^{*} 10^{\wedge C_{0}+C_{1} \operatorname{logtc}+C_{2}(\operatorname{logtc})^{\wedge} 2}$ \\
\hline 0.233 & 0.14342 & 0.0543683 & -0.0089164 & 2.40089 & 0.10848 \\
\hline 0.233 & 0.14342 & 0.0543683 & -0.0089164 & 2.40089 & 0.10848 \\
\hline 0.233 & 0.14342 & 0.0543683 & -0.0089164 & 2.40089 & 0.10848 \\
\hline
\end{tabular}


Table 15 Ajowa River Bridge Project Hydraulics

\begin{tabular}{|c|c|c|c|c|c|c|c|c|c|c|c|c|}
\hline \multicolumn{13}{|c|}{ Dimensional computation for the given Design discharge for the given return period } \\
\hline \multirow{2}{*}{$\begin{array}{c}\text { Brid } \\
\text { ge } \\
\text { span }\end{array}$} & \multirow{2}{*}{$\begin{array}{c}\text { Avera } \\
\text { ge } \\
\text { Chan } \\
\text { nel } \\
\text { slope } \\
(\mathbf{S})\end{array}$} & \multirow{2}{*}{$\begin{array}{l}\text { Dep } \\
\text { th of } \\
\text { flow } \\
(\mathbf{m})\end{array}$} & \multirow{2}{*}{$\begin{array}{c}\text { Mannin } \\
\text { g } \\
\text { Roughn } \\
\text { ess } \\
\text { Coeffici } \\
\text { ent (n) }\end{array}$} & \multirow{2}{*}{\begin{tabular}{c|} 
Sid \\
e \\
slo \\
pe \\
H: \\
V
\end{tabular}} & \multicolumn{2}{|c|}{ Area (A) } & \multicolumn{2}{|c|}{ Perimeter (p) } & \multicolumn{2}{|c|}{$\underset{\circledR}{\text { Hydraulic Radius }}$} & \multicolumn{2}{|c|}{$\begin{array}{c}\text { Design Discharge } \\
\text { Computation }\end{array}$} \\
\hline & & & & & $\begin{array}{c}\text { Rectangu } \\
\text { lar }\end{array}$ & $\begin{array}{c}\text { Trapezoi } \\
\text { dal }\end{array}$ & $\begin{array}{c}\text { Rectangu } \\
\text { lar }\end{array}$ & $\begin{array}{c}\text { Trapezoi } \\
\text { dal }\end{array}$ & $\begin{array}{c}\text { Rectangu } \\
\text { lar }\end{array}$ & $\begin{array}{c}\text { Trapezoi } \\
\text { dal }\end{array}$ & $\begin{array}{c}\text { Rectangu } \\
\text { lar }\end{array}$ & $\begin{array}{c}\text { Trapezoi } \\
\text { dal }\end{array}$ \\
\hline 38 & 0.2078 & 2.45 & 0.1 & 0.5 & 93.1 & 96.101 & 42.9 & 43.478 & 2.170 & 2.2103 & 711.37 & 713.41 \\
\hline
\end{tabular}

Based on above investigations the proposed design of Ajowa river bridge details is as follows,

Depth of flow $2.45 \mathrm{~m}$

Bridge span Length $38 \mathrm{~m}$

Free board $1.2 \mathrm{~m}$

Total depth from river bed to bottom slab of the bridge $3.7 \mathrm{~m}$

\section{CONCLUSION}

- The Delineation of the catchment areas has been accomplished by using GIS Software from the Digital Elevation Models (DEM) of the Project area.

- Run-off or slope or discharge characteristics of the catchment area is determined.

- Location, capacity and type of drainage facilities required and Computation of water run-off quantities to be taken up by drainage structures are carried out using different acceptable calculation methodologies depending on the size of the catchment area and estimated run-off coefficient.

- The run-off coefficients are determined using available information and following field reconnaissance made by hydrologist.

- The bridge details such as depth of flow, length and free board is determined.

\section{REFERENCES}

[1] Atharvi Thorat, Shri.Srishailam C, Akshay Nalawade, Sahil Gore and Sanket Lunawat, Estimation of Hydrological and Hydraulics Parameters for Bridge Design, International Research Journal of Engineering and Technology, 6(3)2019, 5039-5044.

[2] Amulya T H M, Dhanashree, Nerlikar and Rajashri Melannavar, Hydrological Analysis for Proposing New Bridge at Vrishabhavathi River Valley, Laggere, International Journal for Research in Applied Science \& Engineering Technology, 6(1)2018, 743-749.

[3] Azazkhan I. Pathan and Agnihotri P. G, A Combined Approach For 1-D Hydrodynamic Flood Modeling By using Arc-Gis, Hec-Georas, Hec-Ras Interface - A Case Study on Purna River of Navsari City, Gujarat, International Journal of Recent Technology and Engineering, 8(1),2019, 1410-1417.

[4] Sunilkumar P and Vargheese K O, Flood Modelling of Mangalam river using GIS and HEC-RAS, International Journal of Advance Research in Science and Engineering, 6(6)2017, 159-169.

[5] Khyati V. Mistry, Pritika Prajapati and Bijal Chaudhri, Determination of the stage Discharge curve using HEC-RAS, International Journal of Advance Engineering and Research Development, 5(5)2018, 645-649. 
Hydrological and Hydraulics Investigation for the Design of Bridge across Ajowa River at Wuchale Town Amhara Region South Wollo Ethiopia

[6] Hua TIAN and Jia-dong HUANG, Hydrologic Correlation Analysis of Highway Bridge Community Along River, International Conference on Material Science and Civil Engineering (2016), 446-451.

[7] Sunil Kute, Sayali Kakad, Vrushali Bhoye, and Akshada Walunj, Flood Modeling of River Godavari Using HEC-RAS, International Journal of Research in Engineering and Technology, 3(9)2014, 81-87.

[8] Hakim Farooq Ahmad, Akhtar Alam, M. Sultan Bhat and Shabir Ahmad, One Dimensional Steady Flow Analysis Using HECRAS - A case of River Jhelum, Jammu and Kashmir, European Scientific Journal, 12(32)2016, 340-350.

[9] Luay Kadhim Hameed, Calibration of Manning's Friction Factor for Rivers in Iraq Using Hydraulic Model (Al-Kufa River as Case study), International Journal of Innovative Science, Engineering \& Technology, 1(10)2014, 504-515. 